\title{
Colour fastness of screen printed polyamide knitwear to chlorinated water
}

\begin{abstract}
Two polyamide knitwear used in the production of swimwear were analysed. This paper examines the water retention value, the water absorption value and the colour difference after the repeated exposure of the polyamide knitted fabrics, printed with screen printing technique, to the chlorinated water. Screen printing of the samples results in an increase of the water retention value and reduction of the water absorption value for both materials. The colour difference after the series of exposures to the chlorinated water $(\triangle E)$ showed that the trend is the same for all reproduced colours (CMYK), i.e. that the increase in the number of exposures to the chlorinated water results in the increase of the difference between the reproduced colours, for both materials.
\end{abstract}

\section{KEY WORDS}

screen printing, textile printing, colour fastness to chlorinated water, water retention value, water absorption value

\author{
Đorđe Vujčić \\ University of Banja Luka, \\ Faculty of Technology, \\ Graphic engineering, Banja Luka, \\ Bosnia and Herzegovina \\ Corresponding author: \\ Đorđe Vujčić \\ e-mail: \\ djordje.vujcic@tf.unibl.org
}

First recieved: 30.04.2019. Accepted: 12.06.2019.

\section{Introduction}

Expansion in the development of technique and technology leads to new demands that are placed in front of the producers, on a daily basis, despite the field of activity. These requirements also reflected in the printing industry of textile materials. Fashion trends and changes in the market make great pressure on this industry (Gupta, 2001). Nowadays, it is not enough that clothes fulfil only the basic function, but it is also expected to fulfil the personal requirements of the individual, such as visual appeal. Therefore, clothes must fulfil both aesthetic and fashion requirements (Mecheels, 1992; Stančić, 2015).

The main requirement nowadays in the fashion world is a design that is unique and exclusive. Textile material users are increasingly demanding individualization and personalization, through the availability of different styles, colours and design (Choi et al., 2003). Therefore, more and more funds are allocated for the development of products that are tailored to the needs of man, and they are in accordance with the personal requirements of the individual (Grujić, 2010).
The printing in a very simple way contributes to the improvement of the aesthetic value of clothing (Stančić et al., 2014). Aim of this process is to increase the perceived value of garments, in such a way that the user of the product perceives a greater usefulness of the product against its price (Vladić et al., 2014). The printing process of textile materials can be defined as a process of ink transfer, by a certain printing technique, on a textile substrate (Kašiković et al., 2014). From the artistic aspect, this process can be characterized as the art and ability to apply a specific design to the surface of textile material (Tippet, 2002).

There are many different kinds of textile materials in use, as well as various printing techniques that can be used to print them (Dawson \& Hawkyard, 2000; John \& Anandjiwala, 2009; Stančić et al., 2014; Jurič et al., 2015; Kašiković et al., 2015). Printing techniques suitable for printing of textile materials are: screen printing, digital printing and thermal transfer printing (Novaković, Kašiković \& Vladić, 2010). Screen printing is considered to be the dominant printing technique in the textile world (Kiatkamjornwong, 
Putthimai \& Noguchi, 2005; Kašiković, 2012; Kašiković et al., 2012; Onar Çatal, Özgüney \& Akçakoca Kumbasar, 2012; Stančić et al., 2014; Jurič et al., 2015). The advantages of this printing technique are the cost and productivity. Compared to other printing techniques, equipment is usually cheaper and simpler. It is also suitable for long print runs (Lee et al., 2008; Krebs et al., 2009). Another advantage of this printing technique is the ability to print different types and shapes of substrates. One more characteristic of screen printing is usage of different types of inks (Novaković, Pavlović \& Kašiković, 2015).

Among the most important sorption properties are: air permeability, water retention value and relative humidity. Water retention value of textile materials is a very important characteristic of these materials and is directly related to the degree of comfort that the user perceives when wearing clothes made of these materials (Stančić, 2015). Water retention value of textile materials depends largely on the type of fibres, i.e. the creation of chemical bonds between water molecules and fibres. It can be defined as the amount of water retained by the fibre sample after being immersed in water during a certain time and by removing excess water by centrifuging in the centrifuge during a certain time and with a certain number of rotations (Lazić, 2018). During the printing process part of the printing ink is applied to the surface of textile material and other part penetrates into it. Thus, the printing ink covers the surface of the fibres, thereby preventing direct contact and binding of water to the textile fibres (Stančić, 2015).

In many industrial applications, finishing techniques are used to improve functional or aesthetic fabric properties, and to improve product quality, consistency, value and profitability for the manufacturer. For colouring textiles, a substrate with good absorption capacity is required, in order to dye or print fabric evenly and efficiently. The fabric printing using water pigment paste is yet another example that shows the importance of absorption and water transport in the fabrics. In this case, a fabric with moderate absorption capacity is required. If the fabric does not absorb water, the first printed colour will retain on the surface of the material and application of the next colour will then besmear the sample. On the other hand, if the absorption is too large, the paste will penetrate through the back of the fabric and as a result, the colour yield on the surface will be reduced. Therefore, it is necessary to accurately measure the absorption capacity of the moisture to ensure that the edge of the printed sample is sharp and that the desired colour can be achieved. Likewise, in the case of ink-jet printing, the fabric must be wetted with ink, but it must not allow it to spread and spill (Tang et al., 2014).

Since the tested materials are primarily used for the production of swimwear, the printed samples are subjected to exposure to the chlorinated water (pool water). In previous studies, several authors exposed samples to different concentrations of chlorine (Epps, 1987; Siddiqua et al., 2017; Chowdhury, 2018) in order to establish the durability of colouration, both dyed and printed textile materials. It has been found that this parameter has an influence on colour fastness and that it depends on the type of ink and pigment, the printing process, the chlorine concentration and the type of material.

Some of the authors assessed the colour difference with a colorimetric evaluation, while other authors assessed the colour difference with a grey scale evaluation of colour change, after exposure to different influences in their researches. In this research assessment of the samples after exposure to the chlorinated water was done using spectrophotometer and colour difference according to the CIELAB system. To determine value of colour difference there are various formulae that can be used, for example CMC (Clarke, McDonald \& Rigg, 1984), BFD (Luo \& Rigg, 1987), CIE 94 (CIE, 1995) and latest CIE $\triangle E 2000$ (Luo, Cui \& Rigg, 2001). Obtained values of colour differences can be divided into the following groups: $\Delta \mathrm{E}<0,2$ (the colour difference is not perceptible), $\Delta \mathrm{E}$ between 0,2 and 1 (the colour difference is noticeable), $\Delta \mathrm{E}$ between 1 and 3 (the colour difference is perceptible), $\Delta E$ between 3 and 6 (the colour difference is easy perceptible) and $\Delta \mathrm{E}$ over 6 (obvious colours difference) (Schläpfer, 2002). Examination of colour change after repeated exposure to chlorinated water was investigated, to determine how the number of exposures affect the quality and colour change.

This paper examines the water retention value, the water absorption value, and the colour difference after the repeated exposure of the polyamide knitted fabrics to the chlorinated water. These materials are used in the production of swimwear, and it has been noticed that there is an increasing tendency of printing these materials, in order to personalize product and increase the experienced value. Thus, in this paper, the characterization of two polyamide knitwear, determination of their ability to retain and absorb water, before and after the printing process with screen printing technique, and the control of the colour fastness of printed samples to repeated exposure to chlorinated water (pool water), were done.

\section{Methods and Materials}

This research included two polyamide knitwear with left-right weave type (Figure 1). Material characterization was done according to following standards: material composition (International Organization for Standardization, 1833), fabric weight (Institut za standardizaciju Srbije, 1986) and thread count (Institut za standardizaciju Srbije, 2012). These properties are presented in Table 1. 


\section{Table 1}

Characteristics of PA knitwear used in research

\begin{tabular}{|c|c|c|c|c|c|}
\hline Material & Material type & Type of weaves & $\begin{array}{c}\text { Material } \\
\text { composition (\%) }\end{array}$ & $\begin{array}{l}\text { Fabric weight } \\
\qquad\left(\mathrm{g} \mathrm{m}^{-2}\right)\end{array}$ & $\begin{array}{c}\text { Specific Density } \\
\left(\mathrm{cm}^{-1}\right)\end{array}$ \\
\hline$A$ & Knitwear & Left-right & $\begin{array}{c}\text { Polyamide } 75 \% \\
\text { Elastane } 25 \%\end{array}$ & 141.24 & $\begin{array}{c}\text { Vertical: } \\
\text { Dv }=26 \\
\text { Horizontal: } \\
\text { Dh }=30\end{array}$ \\
\hline B & Knitwear & Left-right & $\begin{array}{c}\text { Polyamide } 53 \% \\
\text { Elastane } 47 \%\end{array}$ & 164.36 & $\begin{array}{c}\text { Vertical: } \\
\text { Dv }=23 \\
\text { Horizontal: } \\
\text { Dh }=17\end{array}$ \\
\hline \multicolumn{3}{|l|}{ Method } & ISO 1833 & SRPS F.S2.016 & SRPS EN 14971 \\
\hline
\end{tabular}

a)

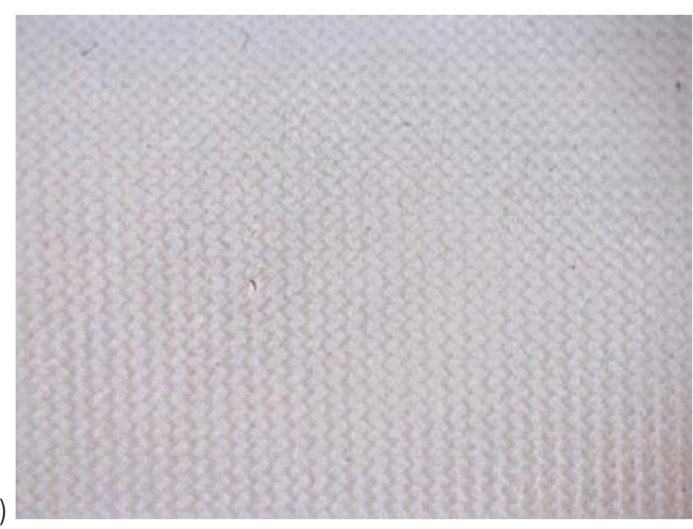

b)

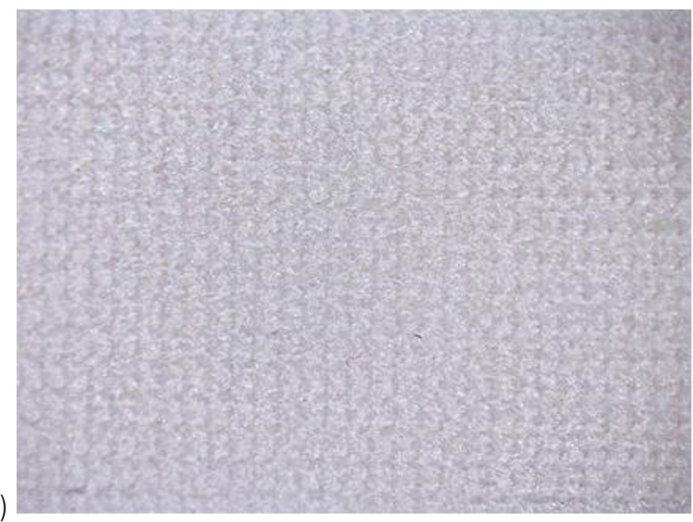

» Figure 1: Tested samples of polyamide knitted fabrics (50x magnification). a) Material $A$, b) Material $B$

The samples were printed with screen printing technique. Printing plate was made using printing screen mesh count of 120 threads per $\mathrm{cm}$ on wooden tubing frames $(50 \times 70 \mathrm{~cm})$. Conventional exposure was conducted using linear positive films. Photosensitive Sericol Dirasol 915 emulsion was used. Light exposure was done using neon lamp at a $10 \mathrm{~cm}$ distance from the mesh. Exposure time was 8 minutes.

Squeegee hardness was 65 Shore Type A, ink fixation was done under the temperature of $180{ }^{\circ} \mathrm{C}$, with the exposure time of 8 seconds. Printing was done with dispersive inks with BEZAPRINT pigment and TUBIFAST AS 30 solder. For process colours - Cyan, Magenta, Yellow and Black were printed. Dimensions of printed patches were in accordance with standards: patch dimension $10 \mathrm{x}$ $10 \mathrm{~cm}$ for water absorption testing and patch dimension $10 \times 4 \mathrm{~cm}$ for testing colour fastness to chlorinated water. For testing water retention value, it was important that printed patches were $1.6 \mathrm{~g}$ in weight.

Determination of the water retention value for textile materials (WRV) was done according to DIN 53814 (Deutsches Institut für Normung, 1974). Air-conditioned samples of material (approximately $1.6 \mathrm{~g}$ ) are cut into small pieces. For every sample four parallel measurements have been done, whereby in every cuvette, which has been previously weighed, was placed $0.4 \mathrm{~g}$ of the sample. Cuvettes with samples have been placed in a glass and previously prepared solvent has been poured over the samples (1 g of non-ionic substance in 1 litter of distilled water). Bubbles have been pushed out with needle and samples prepared this way have been left to stay for 2 hours. The cuvettes were then centrifuged for 20 minutes at 3000 rpm, using CENTRIC 150 A from Tehtnica. After centrifuging, cuvettes with samples were weighed, and from the difference in mass of cuvette with sample after centrifuging and empty cuvette the mass of the processed sample was obtained. Water retention value for fabrics WRV is expressed in percentage (\%) and is calculated according to the expression (1):

$W R V=\frac{W_{w e t}-W_{d r y}}{W_{d r y}} \times 100[\%]$

where:

$W_{\text {wet }}$ - wet weight $[\mathrm{g}]$

$W_{\text {dry }}-$ dry weight $[g]$.

Water absorption value is expressed with amount of absorbed water, which textile material, brought in a balance with the standard atmosphere, may absorb under defined conditions, if it is immersed in water at $20{ }^{\circ} \mathrm{C}$. According to DIN 53923 (Deutsches Institut für Normung, 1978), 5 specimens dimensions $100 \times 100$ mm should be prepared, and brought in a balance with the standard atmosphere. Conditioned specimen is then weighed and attached on the corners, using needles or grippers, to the sieve and immersed in the distilled water. 
Temperature of the water should be $20^{\circ} \mathrm{C}$, and speciment should be $20 \mathrm{~mm}$ under water level. Time of soaking is $60 \pm 3 \mathrm{~s}$. After that specimen together with the sieve is removed from the water, three corners of the material are released, and the sieve is tilted to the horizontal plane in a way that the specimen moves away from the substrate and remains to hang free. This way the water can drain. Draining time is $120 \pm 3 \mathrm{~s}$. After that specimen is placed in weighing container and weighed again. From the difference in specimen mass, before and after procedure, amount of absorbed water is being calculated and expressed in percentage.

Colour fastness to chlorinated water was done according to ISO 105-E03:2010 (International Organization for Standardization, 2010). The process was repeated 10 times with chlorinated water solution of active chlorine concentrations of $100 \mathrm{mg} / \mathrm{l}$. A solution containing 100 $\mathrm{mg}$ of active chlorine per litre was prepared according to the procedure detailed in ISO 105-E03:2010. The solution consisted of $41.5 \mathrm{~mL}$ of sodium hypochlorite solution (20 $\mathrm{mL}$ of sodium hypochlorite solution containing 140-160 $\mathrm{g} / \mathrm{L}$ active chlorine in 1 litre of water), $100 \mathrm{~mL}$ of 14.35 $\mathrm{g} / \mathrm{L}$ potassium dihydrogenphosphate solution and 500 $\mathrm{mL}$ of $20.05 \mathrm{~g} / \mathrm{L}$ disodium hydrogenphosphate dihydrate solution. The $\mathrm{pH}$ of solution was 7.5. Colour fastness to chlorinated water was measured repeatedly four times: before treatment with chlorinated water, after first, fifth and tenth treatment with chlorinated water.

Samples were $10 \times 4 \mathrm{~cm}$ dimensions (three repetitions). The mass of the sample is determined with an accuracy of $1 \mathrm{mg}$. A sufficient quantity of solution was poured in the glass container so that the ratio of the solution to the fabric is 100:1. Sample was immersed in the solution, so it was thoroughly wetted. After that container was closed. Sample was left in container for 1 hour under the temperature of $27 \pm 2{ }^{\circ} \mathrm{C}$ and subdued light in Memmert WNB 22 water bath, and mechanical shaking at 50 strokes per minute with mechanical shaking device Memmert SV 1422. After one hour sample was removed from the container, extracted (hydroextracted) so that solution does not drip, and dried by hanging in air at room temperature. Colour change of treated sample was estimated using Konica Minolta CM-2600d (Konica Minolta Sensing, Inc., Japan) spectrophotometer (standard illumination D65, standard observer angle $10^{\circ}$, measurement geometry $\mathrm{d} / 8, \mathrm{SCl}$ - spectral component included) and colour difference according to CIELab colour system. Measurements were repeated 10 times for every sample, and arithmetic mean of 10 measurements was taken for more accurate result. Same procedure was repeated with two other samples.

\section{Results and Discussion}

\section{Water retention value}

In Figure 2 are shown water retention values of tested samples, before and after printing, with four process colours: cyan (C), magenta (M), yellow (Y) and black (K). It can be noticed that material $B$ has higher water retention value before printing compared to material A. This can be explained by difference in fabric weight between materials. Material A has smaller fabric weight $\left(141.24 \mathrm{~g} / \mathrm{m}^{2}\right)$ than material B $(164.36 \mathrm{~g} /$ $\mathrm{m}^{2}$ ), which leads to conclusion that material $B$ should retain more water. Also, if the density of knitting and the porosity of the structure are considered, it can be noticed that second material has smaller density of knitting, which leads to conclusion that this material has greater possibility of retaining the water molecule in it's structure, namely the water molecules are trapped in the pores of the material and they are not able to free themselves during centrifuging of the samples.

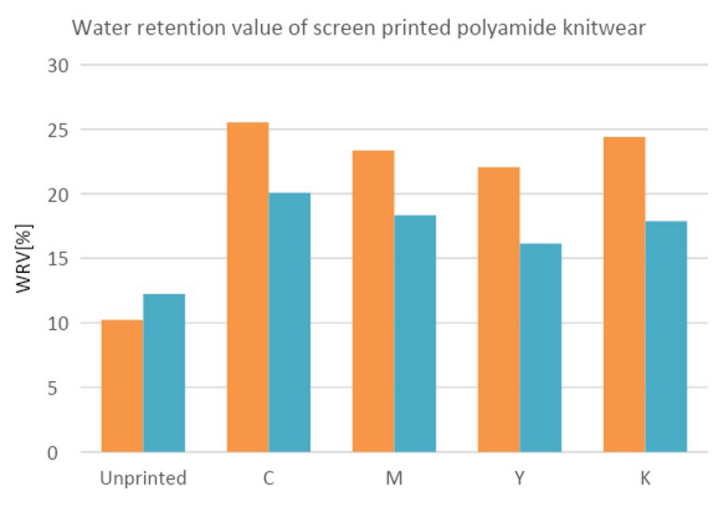

» Figure 2: Water retention value of screen printed polyamide knitwear

Further, for printed samples, an increase in water retention value is observed for both materials. However, this increase for material $A$ is considerably higher than for the material $B$, and after printing material $A$ has a higher water retention value, although it was smaller for this material before printing. Considering the hydrophobicity of the polyamide, the printing ink mainly retains on the surface of the knitwear or eventually fills the pores between the fibres and between the yarn. The molecules of the water are poorly bonded to the polyamide fibres, and they mostly retain on the surface of the materials. After printing, the water molecules are bonded to the particles of the ink, and also, due to the formed layer of ink, when centrifuging the excess water, a great number of the molecules remain trapped between the ink layer and the structure of the material. The formed material-ink layer represents a certain barrier when centrifuging the absorbed water, as well as the water placed on the surface of the material and between the fibres, which can explain the increase in water retention 
capacity after printing. Material B has smaller water retention value after printing, since a great part of the porous material structure is filled with ink during the printing process, which prevents water penetration into these spaces. Therefore, the increase in the amount of retained water, caused by the previously explained processes, is less than it was case for the material A.

\section{Water absorption value}

In Figure 3 are shown obtained water absorption values of tested polyamide knitwear, before and after printing, with four process colours: cyan (C), magenta (M), yellow $(\mathrm{Y})$ and black $(\mathrm{K})$. If water absorption values of samples before printing are being observed, it can be noticed that they are higher for material B. This can be explained by difference in fabric weight between materials. Material A has smaller fabric weight (141.24 $\left.\mathrm{g} / \mathrm{m}^{2}\right)$ than material $\mathrm{B}\left(164.36 \mathrm{~g} / \mathrm{m}^{2}\right)$, which leads to conclusion that material $\mathrm{B}$ should absorb more water.

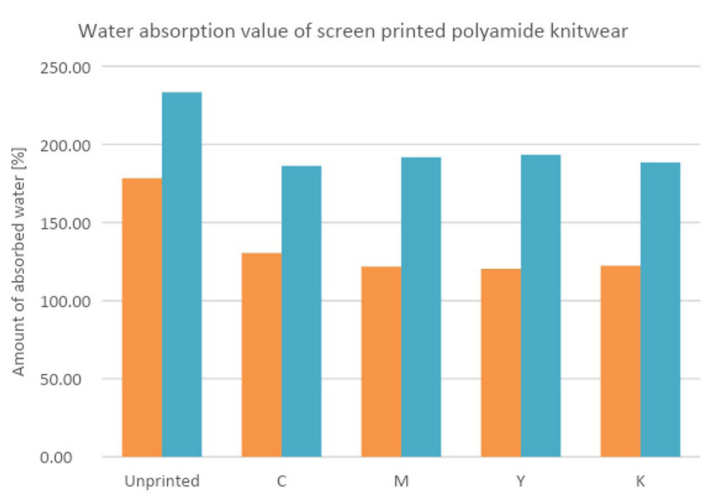

» Figure 3: Water absorption value of screen printed polyamide knitwear

Further, for printed samples, a decrease in water absorption capacity is observed for both materials. Due to the hydrophobicity of the polyamide, when printing the ink mostly retains on the surface of the knitwear or eventually fills the pores between the fibres and between the yarn. After printing, a layer of ink is formed. The ink is partially absorbed into the material, and partly stays on its surface. The formed material-ink layer represents a certain barrier when water is absorbed, since water cannot reach the material and bind. Considering the formed layer of the ink the fibre does not come into direct contact with water, and it is not able to absorb the water. Since the ink does not absorb water, after digging the material, only a certain part of the water, which manages to reach the material and physically absorbs into the fibre, retains in the material.

\section{Colour reproduction analysis}

In table 2 are shown measured values of CIE L*a*b* coordinates of colours, as well as colour differences after repeated exposure of printed material to chlorinat- ed water. As reference values for calculation of colour difference $\left(\Delta E_{2000}\right), L^{*} a * b *$ values of printed samples have been used. Colour differences after every exposure to chlorinated water are calculated compared to these values.

Table 2

Measured values of $\mathrm{CIE} \mathrm{L}^{*} \mathrm{a} \mathrm{b}^{*}$ coordinates of colours and colour difference after repeated exposure of materials printed with CMYK colours to chlorinated water

\begin{tabular}{|c|c|c|c|c|}
\hline Sample & $\mathbf{L}$ & a & b & $\Delta E 2000$ \\
\hline$C A-P$ & 56.90 & -11.63 & -47.04 & - \\
\hline C A-CW1 & 55.70 & -13.54 & -48.28 & 1.62 \\
\hline C A-CW5 & 55.58 & -13.67 & -48.00 & 1.72 \\
\hline C A-CW10 & 55.38 & -13.71 & -47.57 & 1.85 \\
\hline C B-P & 60.44 & -11.49 & -48.37 & - \\
\hline C B-CW1 & 59.78 & -12.40 & -50.52 & 1.01 \\
\hline C B-CW5 & 59.66 & -12.24 & -50.65 & 1.04 \\
\hline C B-CW10 & 59.25 & -12.41 & -49.82 & 1.26 \\
\hline M A-P & 48.81 & 60.45 & -0.22 & - \\
\hline $\mathrm{MA}$ A-CW1 & 47.45 & 63.58 & -0.64 & 1.59 \\
\hline $\mathrm{M}$ A-CW5 & 47.04 & 62.87 & -1.19 & 1.90 \\
\hline M A-CW10 & 46.92 & 61.57 & -1.71 & 2.00 \\
\hline M B-P & 47.93 & 62.86 & 2.26 & - \\
\hline M B-CW1 & 46.82 & 65.97 & 1.62 & 1.39 \\
\hline M B-CW5 & 46.66 & 65.89 & 0.94 & 1.59 \\
\hline M B-CW10 & 46.55 & 65.00 & 0.61 & 1.64 \\
\hline Y A-P & 83.51 & -4.69 & 95.08 & - \\
\hline Y A-CW1 & 84.65 & -6.34 & 99.90 & 1.38 \\
\hline Y A-CW5 & 84.34 & -6.84 & 99.91 & 1.44 \\
\hline Y A-CW10 & 83.30 & -7.68 & 97.32 & 1.54 \\
\hline Y B-P & 86.23 & -5.75 & 96.76 & - \\
\hline Y B-CW1 & 86.71 & -6.94 & 100.37 & 0.89 \\
\hline Y B-CW5 & 86.32 & -7.38 & 99.70 & 0.92 \\
\hline Y B-CW10 & 85.60 & -7.38 & 98.11 & 0.93 \\
\hline$K A-P$ & 21.92 & 2.63 & -5.32 & - \\
\hline K A-CW1 & 16.61 & 2.67 & -10.39 & 5.35 \\
\hline K A-CW5 & 16.07 & 2.81 & -10.38 & 5.57 \\
\hline K A-CW10 & 16.03 & 2.78 & -10.74 & 5.78 \\
\hline K B-P & 22.60 & 4.14 & -5.04 & - \\
\hline K B-CW1 & 17.07 & 4.87 & -10.23 & 5.24 \\
\hline K B-CW5 & 17.00 & 4.93 & -10.23 & 5.52 \\
\hline K B-CW10 & 17.09 & 4.85 & -10.37 & 5.56 \\
\hline
\end{tabular}

Note: first letter stands for colour (C - cyan, $M$ - magenta, $Y$-yellow, $K$-black); letters $A$ and $B$ represent material; $P$ is the mark of printed sample; CW1 is the mark of the sample after the first exposure to chlorinated water; CW5 is the mark of the sample after the fifth exposure to chlorinated water; CW10 is the mark of the sample after the tenth exposure to chlorinated water.

Results compared in Figure 4 show that with increased number of exposures to chlorinated water colour difference for samples printed with cyan colour is also 
being increased both for material $A$ and for material B. What can be noticed is that the colour differences are higher for the material A. It can also be noticed that after the first exposure to the chlorinated water there is a certain value of the colour difference, which does not change significantly with repeated exposures to the chlorinated water. The colour difference for both materials, after the first, and after repeated exposures to chlorinated water is in range from 1 to 3 , which is defined as a perceptible colour difference.

If CIE L*a*b coordinates of reproduced cyan colour after repeated exposure to chlorinated water are being observed, it can be concluded that trend is the same for both materials. After exposure to chlorinated water lightness value is smaller ( $L$ coordinate) and printed sample appears darker. Value of coordinate a is also smaller, which indicates that reflection in green part of the spectrum is higher, and coordinate $b$ is also smaller, which indicates higher reflection in blue part of the spectrum.

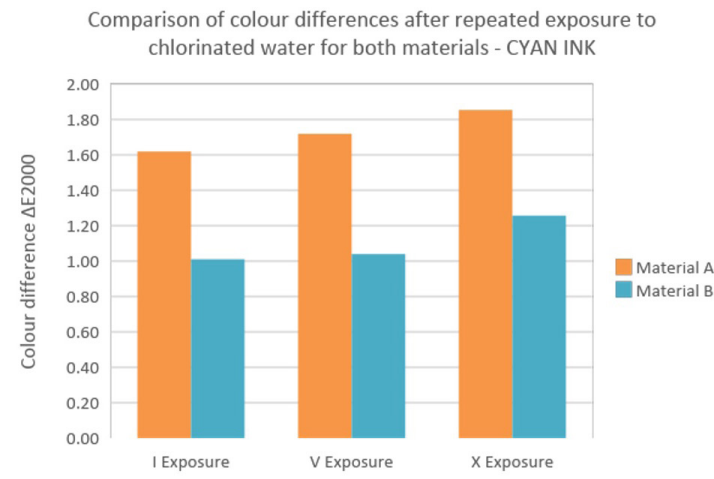

» Figure 4: Comparison of colour differences for both materials after repeated exposure to chlorinated water - cyan ink

Results compared in Figure 5 show that with increased number of exposures to chlorinated water colour difference for samples printed with magenta colour is also being increased both for material A and for material $B$. What can be noticed is that the colour differences are higher for the material A. It can also be noticed that after the first exposure to the chlorinated water there is a certain value of the colour difference, which does not change significantly with repeated exposures to the chlorinated water. The colour difference for both materials, after the first, and after repeated exposures to chlorinated water, for magenta colour is also in range from 1 to 3 , which is defined as a perceptible colour difference.

If coordinates of reproduced magenta colour after repeated exposure to chlorinated water are being observed, it can be concluded that trend is also the same for both materials. After exposure to chlorinated water lightness value is smaller ( $\mathrm{L}$ coordinate) and printed sample appears darker. Value of coordinate $a$ is higher, which indicates that reflection in red part of the spectrum is higher, but it starts to fall off after repeated exposures, and approaches to the initial value. Coordinate $b$ is smaller after repeated exposures to the chlorinated water, which indicates higher reflection in blue part of the spectrum.

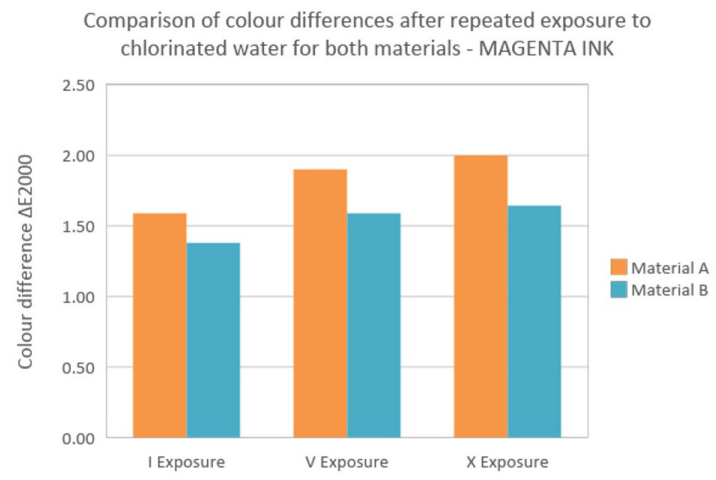

» Figure 5: Comparison of colour differences for both materials after repeated exposure to chlorinated water - magenta ink

Results compared in Figure 6 show that with increased number of exposures to chlorinated water colour difference for samples printed with yellow colour is also being increased both for material A and for material $\mathrm{B}$. What can be noticed is that the colour differences are higher for the material A, as it was for cyan and magenta colour. It can also be noticed that after the first exposure to the chlorinated water there is a certain value of the colour difference, which does not change significantly with repeated exposures to the chlorinated water. The colour difference for material A, after the first, and after repeated exposures to chlorinated water, is in range from 1 to 3 , which is defined as a perceptible colour difference, while this difference for material $B$ is below 1 , after the first, and after repeated exposures to chlorinated water, which is defined as noticeable colour difference.

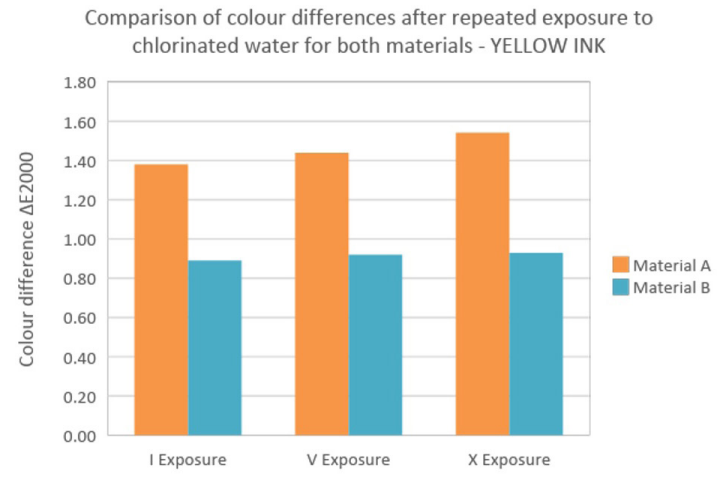

» Figure 6: Comparison of colour differences for different materials after repeated exposure to chlorinated water - yellow ink

After exposure to chlorinated water yellow colour printed on material $A$ has higher value of $L$ coordinate, which starts to fall off after fifth exposures and after tenth 
exposure appears even smaller than initial value, so at the end printed sample appears darker. Value of coordinate $a$ is smaller, which indicates that reflection in green part of the spectrum is higher, and value of coordinate $b$ is first higher, which indicates that reflection in yellow part of the spectrum is higher, and after repeated exposures to the chlorinated water starts to fall off, and after tenth exposure appears smaller than initial value which indicates higher reflection in blue part of the spectrum.

For material $\mathrm{B}$ there is only difference related to coordinate $b$, where its value is still higher than initial after repeated exposures to chlorinated water, thus reflection in yellow part of the spectrum is higher, than it was before exposures.

Results compared in Figure 7 show that with increased number of exposures to chlorinated water colour difference for samples printed with black colour is also being increased both for material $A$ and for material B. What can be noticed is that the colour differences are higher for the material $\mathrm{A}$, as it was case for other colours. It can also be noticed that after the first exposure to the chlorinated water there is a certain value of the colour difference, which does not change significantly with repeated exposures to the chlorinated water. The colour difference for both materials, after the first, and after repeated exposures to chlorinated water, for black colour is in range from 3 to 6 , which is defined as easy noticeable colour difference.

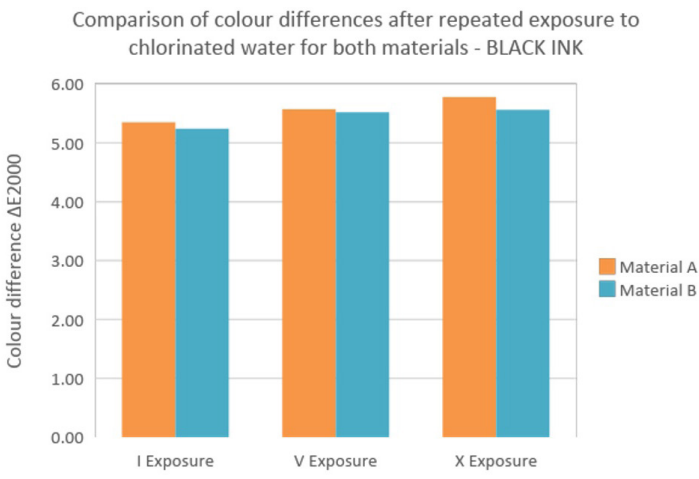

» Figure 7: Comparison of colour differences for different materials after repeated exposure to chlorinated water - black ink

If coordinates of reproduced black colour after repeated exposure to chlorinated water are being observed, it can be concluded that trend is the same for both materials. After exposure to chlorinated water lightness value is smaller ( $L$ coordinate) and printed sample appears darker. Value of coordinate $a$ is higher, which indicates that reflection in red part of the spectrum is higher, but it starts to fall off after repeated exposures, and approaches to the initial value. Coordinate $b$ is considerably smaller already after first exposure to the chlorinated water, which indicates that reflec- tion in blue part of the spectrum is higher. This value is not changing significantly after repeated exposures.

If obtained colour differences for material $A$ and material $B$ are being compared, it can be noticed that for every colour there is the same trend with repeated exposure to chlorinated water, as well as the colour differences for the material A are higher compared to differences for the material B. This can be explained by the characteristics of the materials. Material A has smaller fabric weight, and therefore ink less penetrates the material, and partly retains on the surface of the material. For the material $B$, regarding the higher fabric weight, ink mostly penetrates the material. Exposure of the material A to the chlorinated water leads to the destruction of the surface layer of the ink, removal of the ink particles and colouration, and uniformity of the ink layer. This can also be used to explain that further influence of chlorine leads to slight changes in the colour. For the material B, regarding the higher fabric weight, the bond between ink and material is stronger, and therefore effect of chlorinated water is smaller. This can also be explained by material composition. Material A has higher percentage of polyamide, that is basically hydrophobic and hardly accept ink, which affects quality of the bond ink-material.

Regardless of the differences that exist between the materials, it can be noticed that the colour differences for both materials for cyan, magenta and black are in the same range and differ only for yellow, where for material $A$ they belong to perceptible (from 1 to 3 ) and for material $\mathrm{B}$ they belong to a noticeable colour difference (below 1).

If $\mathrm{L}$ coordinate of the samples is being observed, it can be noticed that value of lightness is smaller for cyan, magenta and black colour after repeated exposures to the chlorinated water. This is conditioned by change in reflection of the surface of printed material. After exposure to the chlorinated water and destruction of the surface layer of the ink, removal of the ink particles and colouration, and uniformity of the ink layer reflection is different and thus also observed colour. Since there is shift in reflection to the blue part of the spectrum for these colours, they appear darker and this affect value of $L$ coordinate also. This change is most noticeable for black colour, where this shift is much higher than in case of other colours. Yellow colour first has higher value of lightness and after repeated exposures lightness approaches to the initial value. Since the yellow colour basically has a high lightness and reflectivity, this change is significantly less noticeable for this colour than for example black colour.

If colour differences for different colours are being observed, it can be noticed that colour differences are the smallest for yellow, and the biggest for black for both materials. It can also be noticed that differences for cyan and magenta are in a similar range. 


\section{Conclusions}

The research included two types of polyamide knitwear. The quality of the prints made on these substrates with screen printing technique has been examined. Considering that this type of textile material is most commonly used for making swimsuits, the water retention value and the water absorption value, as well as the colour fastness to repeated exposure to chlorinated water, has been tested. In order to determine the quality of the print, spectrophotometric analysis of the reproduced colours was performed before and after the series of exposure to the chlorinated water.

If water retention value is being observed, it can be noticed that screen printing of the samples results in an increase of water retention value for both materials. It can also be noticed that the increase of the water retention value after printing is greater for material $A$ and that this material has a higher water retention value after printing, compared to material $B$, although it was less for this material before printing.

Observing water absorption value, based on the obtained results, it can be concluded that the screen printing of polyamide knitwear reduces the water absorption value for both materials. This can be explained by formed material-ink layer.

Further, spectrophotometric measurements have determined the CIE Lab colour coordinates, as well as the colour difference after the series of exposure to the chlorinated water $\left(\Delta \mathrm{E}_{2000}\right)$. The measurement showed that the trend is same for all reproduced colours (CMYK), i.e. that the increase in the number of exposures to the chlorinated water increases the difference between the reproduced colours. It can also be concluded that the difference that occurs after the first exposure is the most significant, and that further repetition of the exposure to the chlorinated water does not affect colour difference significantly. The difference between the reproduced colours after exposure to chlorinated water is due to the destruction of the surface layer of the ink and the removal of the ink particles. Thus, by the spectrophotometric measurement the difference is noticed, primarily because of different reflections of the light from the substrate and ink.

If the behaviour of reproduced colours on material $A$ and material $B$ after the series of exposure to chlorinated water is being compared, it can be concluded that the colour differences occurring on material $A$ are greater compared to the differences on material B, which is caused by the characteristics of the material, respectively fabric weight and material composition.

Further, by comparing the behaviour of the various reproduced colours, it can be concluded that the type of the ink, i.e. the pigment, has a significant effect on the quality of reproduction. Thus, exposure to chlorinated water has the greatest influence on black, while this effect is least reflected on the yellow colour. Exposure to the chlorinated water leads to the destruction of the surface layer of the ink, making the surface of the printed material more reflective. This change is least noticeable in yellow, as this colour has high value of lightness, and most noticeable in black, which has a small value of lightness.

At the end it can be concluded that exposure of screen printed polyamide knitwear to chlorinated water, as well as the frequency of this exposure, significantly affects the quality of prints and reproduction of colours. It can also be concluded that exposure to chlorinated water has a significant effect on both types of material and that there are slight differences due to their characteristics (fabric weight and material composition).

\section{References}

Choi, P.S.R., Yuen, C.W.M., Ku, S.K.A. \& Kan, C.W. (2003) Ink-jet Printing for Textiles. Textile Asia. 34 (10), 21-24. Chowdhury, K. P. (2018) Impact of Different Water Repellent Finishes on Cotton Double Jersey Fabrics. Journal of Textile Science and Technology. 4, 85-99. Available from: doi: 10.4236/ jtst.2018.43006 [Accessed: 10th April 2019].

CIE (1995) Industrial Colour-Difference Evaluation. CIE Publ.116. Central Bureau of the CIE, Vienna, Austria. Report number: 116.

Clarke, F. J. J., McDonald, R. \& Rigg, B. (1984) Modification to the JPC79 Color-difference Formula. Journal of the Society of Dyers and Colorists. 100 (4), 128-132. Available from: doi: 10.1111/j.14784408.1984.tb00969.x [Accessed: 10th April 2019].

Dawson, T. \& Hawkyard, C. J. (2000) A new millennium of textile printing. Review of Progress in Coloration and Related Topics. 30, 7-20. Available from: doi: 10.1111/j.1478-4408.2000. tb03776.x [Accessed: 10th April 2019].

Deutsches Institut für Normung (1974) DIN 53814:197410. Prüfung von Textilien; Bestimmung des Wasserrückhaltevermögens von Fasern und Fadenabschnitten, Berlin, Beuth Verlag.

Deutsches Institut für Normung (1978) DIN 53923:1978-01. Prüfung von Textilien; Bestimmung des Wasseraufnahmevermögens von textilen Flächengebilden, Berlin, Beuth Verlag.

Epps, H. H. (1987) Degradation of Swimwear Fabrics: Effects of Light, Sea Water and Chlorine. Clothing and Textiles Research Journal. 5 (2). Available from: doi: 10.1177/0887302X8700500205 [Accessed: 10th April 2019]. 
Grujić, D. (2010) Uticaj svojstava materijala na toplotno fiziološku udobnost odjeće. PhD thesis. Mašinski fakultet Maribor.

Gupta, S. (2001) Ink-jet Printing- A Revolutionary Ecofriendly Technique for Textile Printing. Indian Journal of Fibre and Textile Research. 26 (1-2), 156-161.

International Organization for Standardization (2010) ISO 105-E03:2010. Textiles- Tests for colour fastness- Part E03: Colour fastness to chlorinated water (swimming-pool water), Geneva, International Organization for Standardization.

International Organization for Standardization (2017) ISO 1833-7:2017 Textiles- Quantitative chemical analysis- Part 7: Mixtures of polyamide with certain other fibres (method using formic acid), Geneva, International Organization for Standardization. Institut za standardizaciju Srbije (1986) SRPS F.S2.016:1986. Tekstil- Metražna roba- Određivanje mase po jedinici dužine i jedinici površine, Belgrade, Institut za standardizaciju Srbije.

Institut za standardizaciju Srbije (2012) SRPS EN 14971:2012. Tekstil - Pletenine - Određivanje broja petlji po jedinici dužine i jedinici površine, Belgrade, Institut za standardizaciju Srbije.

John, M. \& Anandjiwala, R. D. (2009) Surface modification and preparation techniques for textile materials. Surface modification of textiles. Woodhead Publishing Ltd, Cambridge, pp. 1-25.

Jurič, I., Kašiković, N., Stančić, M., Novaković, D., Vladić, G. \& Majnarić, I. (2015) The influence of heat treatment on print mottle of screen printed textile knitted fabrics. Applied Thermal Engineering. 90, 215-220. Available from: doi: 10.1016/j.applthermaleng.2015.07.013 [Accessed: 10th April 2019].

Kašiković, N. (2012) Razvoj modela praćenja procesnih parametara štampe tekstilnih materijala. PhD thesis. Fakultet tehničkih nauka Novi Sad.

Kašiković, N., Novaković, D., Karlović, I. \& Vladić, G. (2012) Influence of ink layers on the quality of ink-jet printed textile materials. Tekstil ve Konfeksiyon. 22 (2), 115-124.

19. Kašiković, N., Novaković, D., Milić, N., Vladić, G., Zeljković, Ž. \& Stančić, M. (2015) Thermovision and Spectrophotometric Analysis of Ink Volume and Material Characteristics Influence on Colour Changes of Heat Treated Printed Substrates. Tehnički vijesnik. 22, 33-41. Available from: doi: 10.17559/ TV-20130928115500 [Accessed: 10th April 2019].

Kašiković, N., Vladić, G., Novaković, D., Stančić, M. \& Milošević, R. (2014) Spektrofotometrijska analiza uticaja toplotnih dejstava na kvalitet otisaka. Savremene tehnologije. 3 (1), 66-71. Available from: doi: 10.5937/ savteh1401066K [Accessed: 10th April 2019].

Kiatkamjornwong, S., Putthimai, P. \& Noguchi, H. (2005) Comparison of textile print quality between inkjet and screen printings. Surface Coatings International Part B: Coatings Transactions. 88 (1), 25-34. Available from: doi: 10.1007/BF02699704 [Accessed: 10th April 2019].
Krebs, F. C., Jørgensen, M., Norrman, K., Hagemann, O., Alstrup, J., Nielsen, T., Fyenbo, J., Larsen, K. \& Kristensen, J. (2009) A complete process for production of flexible large area polymer solar cells entirely using screen printing- first public demonstration. Solar Energy Materials and Solar Cells. 93 (4), 422-441. Available from: doi: 10.1016/j. solmat.2008.12.001 [Accessed: 10th April 2019].

Lazić B. D. (2018) Uticaj različitih postupaka fizičko-hemijskog modifikovanja na strukturu i svojstva vlakana lana. PhD thesis. Tehnološki-metalurški fakultet Beograd.

Lee, T.-M., Choi, Y.-J., Nam, S.Y., You, C.-W., Na, D.-Y., Choi, H.-C., Shin, D.-Y., Kim, K.-Y. \& Jung, K.-I. (2008) Color filter patterned by screen printing. Thin Solid Films. 516 (21), 7875-7880. Available from: doi: 10.1016/j. tsf.2008.05.044 [Accessed: 10th April 2019].

Luo, M. \& Rigg, B. (1987) BFD (I:c) Color-difference Formula Part 1 - Development of the Formula. Journal of the Society of Dyers and Colorists. 103 (2), 86-94. Available from: doi: 10.1111/j.14784408.1987.tb01099.x [Accessed: 10th April 2019].

Luo, M. R., Cui, G. \& Rigg, B. (2001) The Development of the CIE2000 Color difference Formula: CIEDE2000. Color Research \& Application. 26 (5), 340-350. Available from: doi: 10.1002/ col.1049 [Accessed: 10th April 2019].

Mecheels, J. (1992) Anforderungsprofile für Funktionsgerechte Bekleidung. DWI-Schriftenreihe des Deutschen Wollforschungsinstitutes an der TH Aachen, Aachener Teksiltagung. 109, 263-268.

Novaković, D., Kašiković, N. \& Vladić, G. (2010) Integrating Internet Application in to the Workflow for Costumisation of Textile Products. Proceedings of International Joint Conference on Environmental and Light Industry Technologies, 18-19 November 2010, Budapest, Hungary. pp. 471-476.

Novaković, D., Pavlović, Ž. \& Kašiković, N. (2015) Tehnike štampe- praktikum za vežbe. Novi Sad, Republic of Serbia, Fakultet tehničkih nauka.

Onar Çatal, D., Özgüney, A. T. \& Akçakoca Kumbasar, E. P. (2012) The Influence of Rheological Properties of the Pretreatment Thickeners on Ink-jet Printing Quality. Tekstil ve Konfeksiyon. 22 (4), 309-316.

Schläpfer, K. (2002) Farbmetrik in der grafischen Industrie. St. Gallen, UGRA.

Siddiqua, U.H., Ali, S., Hussain, T., Bhatti, H. N. \& Asghar, M. (2017) The Dyeing Process and the Environment: Enhanced Dye Fixation on Cellulosic Fabric Using Newly Synthesized Reactive Dye. Pol. J. Environ. Stud. 26 (5), 2215-2222. Available from: doi: 10.15244/ pjoes/68430 [Accessed: 10th April 2019].

Stančić, M. (2015) Model toplotnih svojstava štampanih odjevnih predmeta. PhD thesis. Fakultet tehničkih nauka, Novi Sad, Republika Srbija.

Stančić, M., Kašiković, N., Novaković, D., Dojčinović, I., Vladić, G. \& Dragić, M. (2014) The Influence of Washing Treatment on Screen Printed Textile Substrates. Tekstil ve Konfeksiyon. 24 (1), 96-104. 
Tang Ka-Po, M., Kan, C.-W. \& Fan, Jin-tu (2014) Evaluation of water absorption and transport property of fabrics. Textile Progress. 46 (1), 1-132. Available from: doi: 10.1080/00405167.2014.942582 [Accessed: 10th April 2019].

Tippet, B.G. (2002) The Evolution and Progression of Digital Textile Printing. Orangeburg, New York, USA, Digital Printing Systems. Available from: http://brookstippett.com/docs/ Print2002-BGT.pdf [Accessed: 10th April 2019].

Vladić, G., Sadžakov, M., Kašiković, N., Milić, N. \& Stančić, M. (2014) Uticaj štampanih boja na doživljenu vrijednost tekstilnog proizvoda. Zbornik radova: Četvrti naučno stručni skup sa međunarodnim učešćem Tendencije razvoja i inovativni pristup u tekstilnoj industriji- Dizajn, Tehnologija, Menadžment, 06-07 June 2014, Belgrade, Republic of Serbia. pp. 106-111.

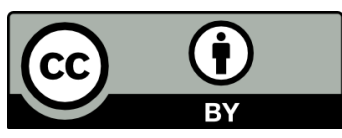

(C) 2019 Authors. Published by the University of Novi Sad, Faculty of Technical Sciences, Department of Graphic Engineering and Design. This article is an open access article distributed under the terms and conditions of the Creative Commons Attribution license 3.0 Serbia (http://creativecommons.org/licenses/by/3.0/rs/). 